\title{
Penyusunan Peta Desa Dalam Kegiatan Pengabdian Masyarakat Hibah Peta di Kelurahan Jebres, Kecamatan Jebres, Kota Surakarta
}

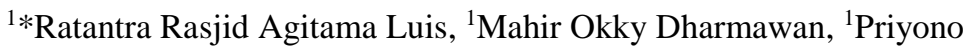 \\ ${ }^{1}$ Program Studi Geografi, Fakultas Geografi, \\ Universitas Muhammadiyah Surakarta \\ Jl. Ahmad Yani, Pabelan, Kartasura, Surakarta 57162, Jawa Tengah, Indonesia \\ *Penulis korespondensi, email: ratantrar.a.1@gmail.com
}

(Received: 8 April 2021/Accepted: 3 May 2021/Published: 31 July 2021)

\begin{abstract}
Abstrak
Kelurahan Jebres merupakan kelurahan yang memiliki luas terbesar ke-4 di Kota Surakarta. Sehingga diperlukan informasi berupa peta administrasi dan fasilitas umum yang dapat digunakan sebagai penunjang pemerintah desa dalam mengurus rumah tangganya. Tujuan pengabdian masyarakat ini adalah pemetaan desa sebagai dasar dalam pembangunan daerah kawasan Kelurahan Jebres Kota Surakarta. Metode yang digunakan di antaranya survei, tahap persiapan, proses pembuatan peta, print out sementara, print out tetap, dan serah terima peta. Kegiatan pengabdian masyarakat di Kelurahan Jebres menghasilkan peta desa yang berisi informasi geospasial yang dapat ditemui di wilayah tersebut. Informasi tersebut berupa batas wilayah administrasi, jaringan/infrastruktur transportasi, perairan, sarana dan prasarana. Citra yang ditampilkan pada peta desa tersebut memberikan gambaran tutupan lahan di Kelurahan Jebres. Penggunaan lahan pada titik - titik tertentu mempunyai kemungkinan terjadi alih fungsi lahan, sehingga menjadi pemanfaatan lahan baru. Oleh karena itu, penyajian peta perlu dilakukan pembaharuan seiring berjalannya waktu untuk menyesuaikan kondisi terbaru yang ada di Kelurahan Jebres. Dalam perencanaan pembangunan, peta tersebut dimanfaatkan sebagai bahan analisis wilayah dengan memperhatikan tutupan lahan. Selain itu, tingkat kerapatan permukiman dapat dijadikan bahan analisis untuk perencanaan pembangunan berupa fasilitasfasilitas umum yang dapat dimanfaatkan oleh masyarakat. Kelurahan Jebres didominasi permukiman, hanya sedikit ruang terbuka hijau yang tersedia. Pengalihan lahan untuk ruang terbuka hijau dapat direncanakan dengan memanfaatkan peta tersebut.
\end{abstract}

Kata Kunci : pemerataan pembangunan, peta, Jebres

\begin{abstract}
Kelurahan Jebres is a sub-district which has the 4th largest area in the City of Surakarta. So that information is needed in the form of administrative maps and public facilities that can be used to support the village government in managing the household. The purpose of this community service is to map the village as the basis for the regional development of the Jebres Kelurahan, Surakarta City. The methods used include surveys, the preparation stage, the map making process, temporary print outs, permanent print outs, and map handover. Community service activities in Jebres Village have resulted in a village map containing geospatial information that can be found in the area. This information is in the form of administrative boundaries, transportation networks / infrastructure, waters, facilities and infrastructure. The image displayed on the village map provides an overview of land cover in Jebres Village. Land use at certain points has the possibility of changing land functions, so that it becomes new land use. Therefore, the presentation of the map needs to be updated over time to adjust to the latest conditions in Jebres Village. In development planning, the map is used as material for area analysis by taking into account land cover. In addition, the level of settlement density can be used as an analysis material for development planning in the form of public facilities that can be
\end{abstract}


utilized by the community. Kelurahan Jebres is dominated by settlements, with only a few green open spaces available. The transfer of land for green open space can be planned using this map.

Keywords : equitable development, map, Jebres

\section{Pendahuluan}

Mengingat pengabdian masyarakat merupakan perwujudan dari akademisi yang hadir di tengah masyarakat yang melibatkan sivitas akademik seperti halnya mahasiswa, dosen, alumni, dan tenaga kependidikan lainnya. Selain itu juga pengejawantahan dari Tri Dharma Perguruan Tinggi yaitu pengabdian yang dalam pelaksanaannya tidak terlepas dari dua dharma yang lainnya. Pembuatan peta desa merupakan salah satu upaya dalam rangka mengimplementasikan bagian integral Tri Dharma Perguruan Tinggi yaitu pengabdian kepada masyarakat dengan secara suka rela menyumbangkan beberapa peta kepada instasi pemerintahan desa. Berdasarkan peraturan Menteri Dalam Negeri Republik Indonesa Nomor 45 Tahun 2016 Tentang Pedoman dan Penegasan Batas Desa maka hal tersebut perlunya peta desa guna memenuhi hal tersebut sebagai instrumen pendukung dalam menerapkan peraturan tersebut. Geoportal Kebijakan Satu Peta yang telah diluncurkan oleh Presiden RI Bapak Joko Widodo bertujuan menyediakan satu peta yang akurat dan akuntabel di Jakarta, pada Selasa (11/12). Peraturan Presiden Nomor 9 Tahun 2016 dan Kebijakan Ekonomi VIII yang mengatur tentang Program Percepatan Kebijakan Satu Peta sejak tahun 2016. Dalam pelaksanaan Nawa Cita salah satu program prioritasnya yaitu Kebijakan Satu Peta. Dengan Kebijakan Satu Peta ini, penyediaan infrastruktur, penerbitan izin dan hak atas tanah, perencanaan pembangunan, serta berbagai kebijakan nasional dapat mengacu pada data spasial yang akurat.

Kelurahan Jebres adalah salah satu diantara 11 kelurahan yang berada di Kecamatan Jebres, Kota Surakarta. Kelurahan Jebres mempunyai luas wilayah 317,5 ha, memiliki 36 Rukun Warga (RW), dan 128 Rukun Tetangga (RT) dengan jumlah penduduk kurang lebih 33.455 jiwa (Dokumen Badan Pusat Statistik Kota Surakarta, 2020). Kelurahan Jebres menjadi salah satu wilayah yang memiliki peranan penting terhadap perkembangan Kota Surakarta terutama dalam aspek pembangunan. Aspek pembangunan yang terus ditingkatkan oleh pemerintah Kelurahan Jebres untuk mengembangkan wilayahnya serta menjadikan daya tarik tersendiri bagi wilayah tersebut, selain itu di Kelurahan Jebres banyak melakukan pembenahan pada aspek pembangunan daerah.

Kelurahan Jebres mempunyai luas wilayah terbesar kedua di Kecamatan Jebres. Kelurahan Jebres menjadi pusat perekononiam dan pusat perdagangan dari Kecamatan Jebres karena fasilitas - fasilitas umum terdapat di kelurahan tersebut. Berbeda dengan kelurahan lain yang ada di Kecamatan Jebres, fasilitasnya tidak selengkap di Kelurahan Jebres. Namun, dibalik lengkapnya fasilitas umum yang ada, ternyata Kelurahan Jebres mempunyai jumlah penduduk miskin dan rentan resiko sosial tertinggi di Kecamatan Jebres sebanyak 901 rumah tangga penduduk miskin dan 2655 rumah tangga penduduk rentan resiko sosial (Dokumen Badan Pusat Statistik Kota Surakarta, 2020). Nampaknya pembangunan yang ada di pusat daerah belum dirasakan oleh masyarakat yang ada di sub daerah. Artinya, hasil - hasil pembangunan belum mampu menjangkau pemerataan kahidupan masyarakatnya. Tidak meratanya hasil pembangunan mengakibatkan kesenjangan antar wilayah. Salah satu kesenjangannya adalah di sektor perekonomian. Satu wilayah dengan wilayah lainnya terjadi kesenjangan ekonomi hal ini dikarenakan adanya faktor pendorong yaitu ketimpangan ketersediaan infrastruktur.

Upaya mengurangi kesenjangan yang dilakukan pemerintah salah satunya dengan mengeluarkan kebijakan pembangunan diantaranya dengan memberlakukan UU No. 32 tahun 2004 tentang Otonomi Daerah. Oleh karena itu, daerah mempunyai wewenang dalam mengatur rumah tangganya sendiri dengan memanfaatkan potensi pada setiap wilayahnya. Desa/kelurahan menjadi tingkat dasar yang menjadi objek wilayah pembangunan. Untuk menciptakan sebuah daerah yang lebih baik, harus diperbaiki terlebih dahulu dari paling bawah, dalam hal ini adalah 
tataran desa/kelurahan. Oleh karena itu, fokus pemerataan pembangunan di tingkat desa/kelurahan tidak boleh diabaikan guna mendukung terbentuknya daerah yang makmur. Keberadaan fasilitas umum seperti rumah sakit, taman kota, kampus perkuliahan ada universitas sebelas maret dan institut seni indonesia, dan taman satwa taru jurug yang ada di Kelurahan Jebres ternyata tidak menjamin terhadap kondisi perekonomian masyarakatnya.

Peta merupakan gambaran permukaan bumi yang ditampilkan dalam bidang datar. Kenampakan yang tertuang didalam peta dapat dijadikan sumber informasi oleh pemerintah selaku pemangku kebijakan dan ahli perencanaan untuk menentukan keputusan pada proses pembangunan. Peta yang dibuat pada tahun terbaru atau terupdate dengan menggunakan data data terbaru tentunya akan menghasilkan data atau informasi secara faktual dan mutakhir sehingga kebijakan dari pemerintah setempat dinilai berintegritas.

Kelurahan Jebres merupakan kelurahan yang memiliki luas terbesar ke-4 di Kota Surakarta. Fasilitas umum seperti rumah sakit, taman kota, kampus perkuliahan ada universitas sebelas maret dan institut seni indonesia, dan taman satwa taru jurug yang dapat diakses oleh warga setempat maupun pendatang hampir semuanya tersedia di kelurahan tersebut. Wilayahnya didominasi oleh permukiman padat penduduk. Sehingga diperlukan informasi berupa peta administrasi dan fasilitas umum yang dapat digunakan sebagai penunjang pemerintah desa dalam mengurus rumah tangganya. Namun, keberadaan peta desa yang ada di Kelurahan Jebres masih sangat sederhana, karena hanya memberikan informasi batas wilayahnya saja. Peta yang ada di kelurahan tersebut juga belum memenuhi kaidah kartografi dan tidak menampilkan informasi yang optimal, sehingga pemanfaatan petanya pun juga kurang optimal, hanya digunakan untuk pajangan dinding saja. Oleh karena itu, perlu dilakukannya pembaharuan dengan meningkatkan kualitas peta desa yang ada di Kelurahan Jebres agar dapat dimanfaatkan perengkat desa dengan optimalisasi sajian informasi geospasial yang baik.

Tujuan kegiatan pengabdian masyarakat ini adalah pemetaan desa sebagai dasar dalam pembangunan daerah kawasan Kelurahan Jebres. Peningkatan kesejahteraan desa perlu didukung dari berbagai pihak salah satunya adalah lembaga pendidikan perguruan tinggi. Oleh karena itu, pengabdian masyarakat ini menjadi sebuah bentuk dukungan kita dalam meningkatkan kesejahteraan desa dengan pemanfaatan informasi geospasial secara optimal.

\section{Metode}

Kegiatan pengabdian masyarakat berupa pembuatan peta desa dilakukan di Kelurahan Jebres, Kecamatan Jebres, Kota Surakarta. Kegiatan ini terdiri dari beberapa tahapan yaitu survei dengan pendahuluan berupa permohonan izin kepada Pemerintah Kelurahan Jebres dan memberikan penjelasan terkait maksud kegiatan dan manfaat yang bisa diperoleh. Selain itu, pemaparan terkait alur kegiatan juga disampaikan agar mitra memahami betul alur pelaksanaan kegiatan dari awal hingga akhir. Selanjutnya yaitu tahap pengumpulan data - data primer berupa survei titik - titik fasilitas umum yang ada di Kelurahan Jebres serta data sekunder dari dokumen perangkat Kelurahan Jebres dan dari Badan Pusat Statistik Kota Surakarta tahun 2021 dalam proses pembuatan peta desa. Kemudian proses pembuatan peta desa, setelah itu di printout sementara untuk dikonsultasikan keadaan perangkat desa. Jika sudah bisa langsung di printout peta desa dengan skala 1:5000 yang sudah dikonsultasikan dengan ukuran A0 dan dilakukan pembingkaian/finishing. Tahapan yang terahir yaitu prosesi penyerahan peta desa.

Bahan dan alat yang mendukung pelaksanaan kegiatan di Kelurahan Jebres ini adalah citra Lansat TM resolusi spasialnya 30 meter perekaman tahun 13 Maret tahun 2020 yang telah tergeoreferensi dengan teknik koreksi geometri, software Sistem Informasi Geografis (SIG), laptop/komputer, dan alat percetakan. Berikut ini adalah penjelasan terkait tahapan pengabdian masyarakat di Kelurahan Jebres :

1. Survei pendahuluan dengan mendatangi kantor kelurahan untuk menjelaskan maksud dan tujuan kegiatan kepada perangkat desa setempat, menjelaskan alur pelaksanaan kegiatan, dan memaparkan manfaat yang bisa diperoleh dari kegiatan pengadaan peta desa tersebut. 
2. Tahap persiapan dengan melakukan pengumpulan data - data pendukung dalam proses pembuatan peta desa. Data tersebut berupa batas wilayah sesuai dengan data arsip di Kelurahan Jebres, data citra terbaru tahun 2020 yang tergeoreferensi, titik koordinat fasilitas umum yang terdapat di lokasi mitra, dan persiapan perangkat lunak SIG yang digunakan untuk proses pembuatan peta desa.

3. Proses pembuatan peta adalah dengan melakukan digitasi terlebih dahulu untuk membuat batas wilayah yang sesuai dengan arsip data kelurahan. Setelah itu dilakukan input data koordinat fasilitas umum dan kenampakan umum lainnya seperti sungai dan jalan yang diperoleh dari data sekunder. Langkah terakhir dalam proses pembuatan adalah layout dan printout sementara.

4. Hasil dari printout sementara dikonsultasikan terlebih dahulu kepada perangkat desa apakah sudah sesuai atau perlu penambahan informasi lainnya.

5. Selanjutnya adalah printout peta desa yang sudah dikonsultasikan dengan ukuran A0 dan dilakukan pembingkaian/finishing

6. Melakukan serah terima peta desa kepada perangkat desa yang dilakukan di Kantor Kelurahan Jebres dan disaksikan perwakilan dari masyarakat yang diwakili oleh ketua ketua RT di Kelurahan tersebut.

Partisipasi mitra dalam pelaksanaan kegiatan ini adalah membantu dalam pengumpulan data data pendukung pembuatan peta desa, mempersiapkan agenda serah terima peta desa, dan memberikan sosialiasi pemanfaatan peta desa kepada masyarakat agar pemahaman terkait manfaat dari peta desa tidak hanya menjadi konsumsi perangkat desa namun juga masyarakat pada umumnya yang dapat diakses secara gratis.

\section{Hasil dan Pembahasan}

Kegiatan pengabdian masyarakat ini telah dilaksanakan pada hari Jumat Tanggal 19 Maret 2021 bertempat di Pendapa Alit Kelurahan Jebres Kecamatan Jebres Kota Surakarta secara luring atau offline dengan menerapkan protokol kesehatan karena pelaksanaan masih dalam kondisi pandemi. Kegiatan ini terdiri dari serangkaian acara. Kegiatan pengabdian masyarakat di Kelurahan Jebres menghasilkan peta desa yang berisi informasi geospasial dapat ditemui di wilayah tersebut. Informasi tersebut berupa batas wilayah administrasi, jaringan/infrastruktur transportasi, perairan, sarana dan prasarana. Kontribusi mendasar dari kegiatan ini adalah peningkatan kemampuan masyarakat dan pemerintah desa setempat dalam merencanakan, melaksanakan dan mengevaluasi upaya perencanaan pembagunan yang akan dilaksanakan di kemudian hari sesuai dengan kebutuhan dan kondisi masyarakat setempat dengan melihat peta yang sudah dibuat. Selain itu adanya laporan secara legal sebagai bukti dokumen ilmiah dengan adanya pengabdian masyarakat ini berupa laporan pengabdian masyarakat di Kelurahan Jebres Kota Surakarta.

Peta desa tersebut dibuat dengan menggunakan perangkat lunak SIG yaitu, ArcGIS dan laman SAS Planet. Laman SAS Planet digunakan untuk mendapatkan data citra beresolusi tinggi yaitu citra Lansat TM resolusi spasialnya 30 meter perekaman tahun 13 Maret tahun 2020 yang telah tergeoreferensi dengan teknik koreksi geometri sehingga kenampakan objek yang terekam bisa terlihat jelas. ArcGIS digunakan untuk proses pengolahan data mulai dari pemotongan citra, penambahan atribut, dan layout. Penyajian peta desa tersebut sudah disesuaikan dengan Peraturan Kepala Badan Informasi Geospasial Nomor 3 Tahun 2016 Tentang Spesifikasi Teknis Penyajian Peta Desa. Mengetahui informasi potensi apa saja yang ada di suatu desa atau kelurahan dan guna keperluan pembangunann wilayah dengan data yang lebih spesifik yaitu dengan Pembuatan peta potensi desa. 
Peta yang ada di Kelurahan Jebres sebelumnya belum memenuhi standart kaidah penulisan peta selain itu hanya menyajikan informasi lampau atau yang telalh berlalu. Oleh karena itu, perlu dilakukannya pembaharuan dengan meningkatkan kualitas peta desa yang ada di Kelurahan Jebres agar dapat dimanfaatkan perengkat desa dengan optimalisasi sajian informasi geospasial yang baik. Maka dari itu peta ini diharapkan nantinya dapat meningkatkan kualitas peta desa yang ada di Kelurahan Jebres agar dapat dimanfaatkan dan berguna bagi perangkat desa untuk berbagai hal. Gambar 1 berikut adalah peta desa Kelurahan Jabres yang disajikan dengan skala 1:5000.

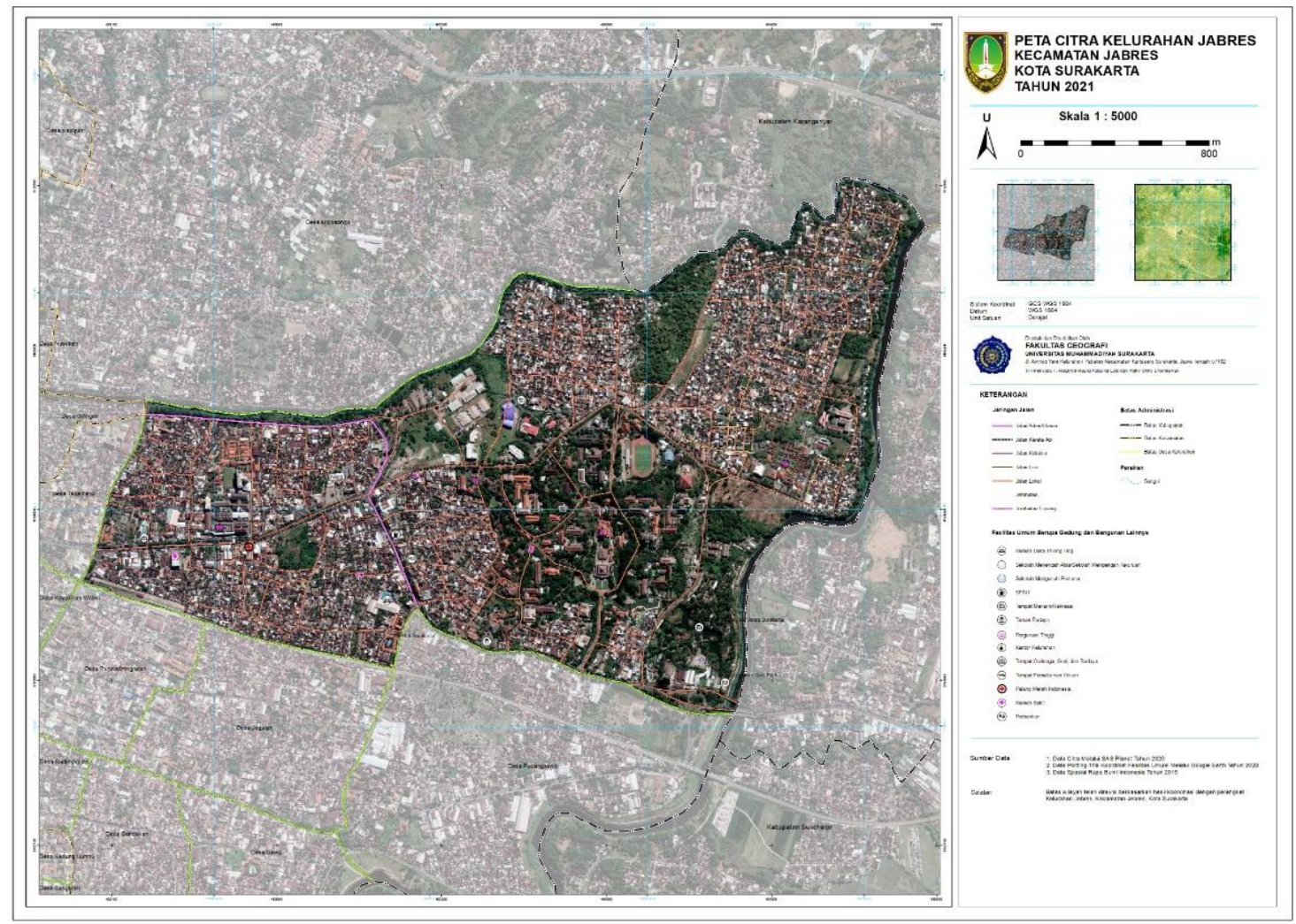

Gambar 1. Peta Citra Kelurahan Jebres

Citra yang ditampilkan pada Gambar 1. tersebut memberikan gambaran mengenai tutupan lahan yang terdapat di Kelurahan Jebres. Penggunaan lahan pada titik - titik tertentu mempunyai kemungkinan terjadi alih fungsi lahan, sehingga menjadi pemanfaatan lahan yang baru. Perubahan penggunaan lahan tersebut dapat terjadi karena tujuan tertentu. Oleh karena itu, penyajian peta perlu dilakukan pembaharuan seiring berjalannya waktu untuk menyesuaikan kondisi terbaru dari kenampakan permukaan bumi yang ada di Kelurahan Jebres, sehingga penyajian peta akan lebih akurat dan pemanfaatannya akan lebih optimal.

Dalam hal perencanaan pembangunan, peta tersebut dapat dimanfaatkan sebagai bahan analisis wilayah dengan memperhatikan tutupan lahan yang ada di wilayah perencanaan. Selain itu, tingkat kerapatan permukiman juga dapat dijadikan bahan analisis untuk perencanaan pembangunan berupa fasilitas - fasilitas umum yang dapat dimanfaatkan oleh masyarakat. Wilayah Kelurahan Jebres didominasi dengan permukiman. Hanya terdapat sedikit ruang terbuka hijau yang tersedia. Pengalihan lahan untuk ruang terbuka hijau juga dapat direncanakan dengan memanfaatkan peta tersebut. 


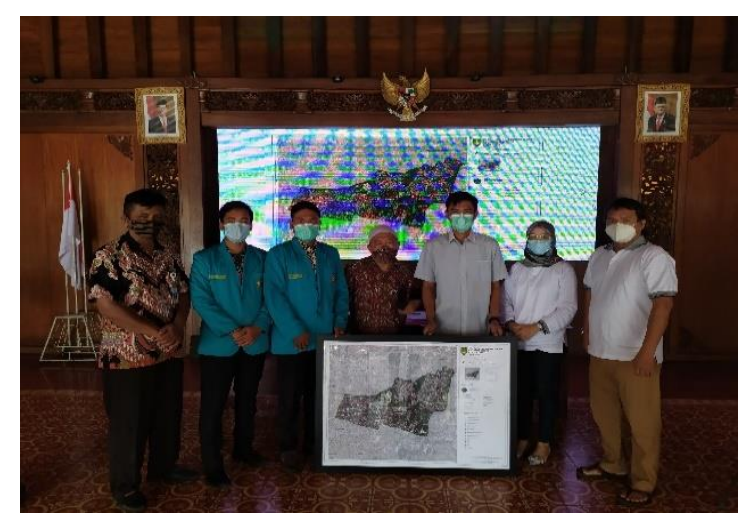

(a)

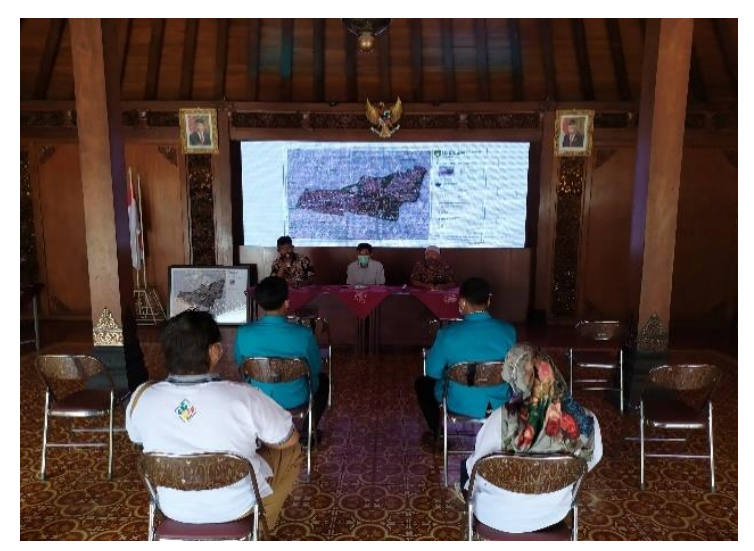

(c)

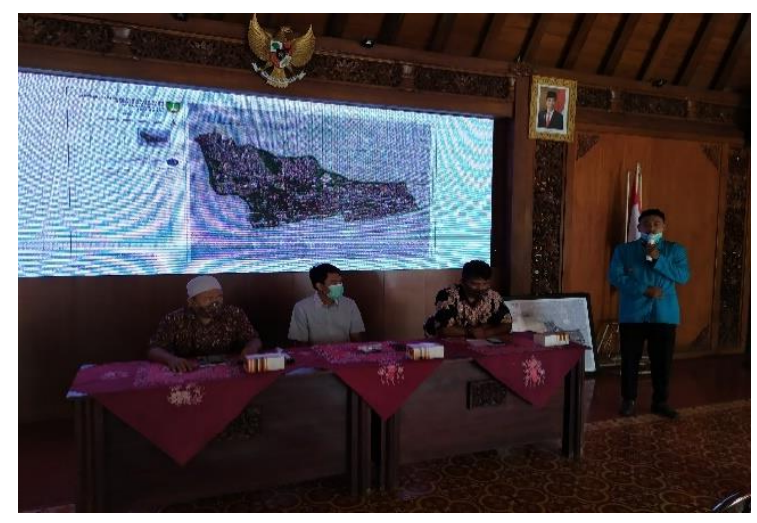

(b)

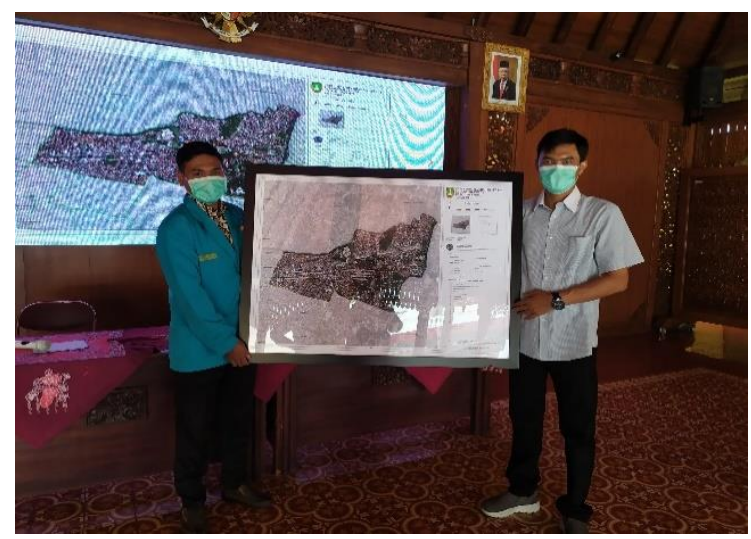

(d)

Gambar 2. Kegiatan Penyerahan Peta di Kelurahan Jebres

Dokumentasi dalam Gambar 2 tersebut merupakan forum prosesi penyerahan hibah peta dalam pengabdian masyarakat yang dilaksanakan di pendapa alit Kelurahan Jebres Kecamatan Jebres Kota Surakarta. Pada foto (a) yaitu sesi foto bersama yang terdiri dari tim pengabdian, perwakilan fakultas, perwakilan perangkat desa Jebres yang diwakili oleh Luah Jebres dan sekdes serta perwakilan pimpinan LSM. Foto (b) merupakan sambutan dari ketua tim pengabdian. Selanjutnya foto (c) merupakan dokumentasi pada saat forum berlangsung dan yang terakhir foto (d) penyerahan dari ketua tim pengabdian kepada Lurah Jebres. Pihak mitra sangat berterima kasih dengan adanya hibah peta tersebut sehingga bersedia untuk menjalin hubungan mitra untuk ke depannya dalam rangka kepentingan akademik yang lain. Harapannya peta tersebut dapat di gunakan sebaik - baiknya dan di gunakan sebagaimana mestinya.

Tabel. 1 Tingkat Kepuasan Mitra dalam Kegiatan Pengabdian Masyarakat Serah Terima Peta Desa di Kelurahan Jebres

\begin{tabular}{ccccc}
\hline NO & \multicolumn{1}{c}{ INDIKATOR } & $\begin{array}{c}\text { PERSENTASE } \\
\text { PUAS }\end{array}$ & $\begin{array}{c}\text { PERSENTASE } \\
\text { CUKUP PUAS }\end{array}$ & $\begin{array}{c}\text { PERSENTASE } \\
\text { TIDAK PUAS }\end{array}$ \\
\hline & $\begin{array}{l}\text { Perencanaan pengabdian } \\
\text { yang dilakukan oleh } \\
1\end{array}$ & $90 \%$ & $10 \%$ & $0 \%$ \\
$\begin{array}{l}\text { Mahasiswa FG UMS telah } \\
\text { sesuai dan memenuhi }\end{array}$ & & & \\
\hline
\end{tabular}




\begin{tabular}{llll}
\hline & $\begin{array}{l}\text { kebermanfaatan dan } \\
\text { kepuasan mitra pada program } \\
\text { pengabdian }\end{array}$ & & \\
2 & $\begin{array}{l}\text { Pelaksanaan program sesuai } \\
\text { dengan target yang } \\
\text { dibutuhkan mitra }\end{array}$ & $100 \%$ & $0 \%$ \\
\hline $\begin{array}{l}\text { Pelaksanaan program } \\
\text { berjalan lancar } \\
\text { Perlunya keberlanjutan } \\
\text { program evaluasi dan } \\
\text { monitoring }\end{array}$ & $86 \%$ & $14 \%$ & $0 \%$ \\
\hline
\end{tabular}

Berdasarkan Tabel 1 dapat diketahui tingkat kepuasan mitra pengabdian berdasarkan 5 (lima) indikator yang telah ditetapkan. Total jumlah responden ialah 5 responden yang hadir dalam kegiatan penyerahan peta desa tersebut, kemudian akan dipersentasekan sesuai dalam kategorinya yaitu kategori Puas, Cukup Puas, dan Tidak Puas. Dalam indikator pertama tentang "Perencanaan pengabdian yang dilakukan oleh Mahasiswa FG UMS telah sesuai dan memenuhi kebermanfaatan dan kepuasan mitra pada program pengabdian" mendapatkan skor kepuasan sebanyak $90 \%$. Keberhasilan angka 90\% merasakan kepuasan atas perencanaan pengabdian yang dilakukan oleh mahasiswa FG UMS merupakan indikator yang dapat menjelaskan keberhasilan kegiatan penyerahan peta desa yang telah memperhatikan kebutuhan mitra dan kesesuaian perencanaan program yang telah di tetapkan.

Indikator kedua "Pelaksanaan program sesuai dengan target yang dibutuhkan mitra" dengan skor kepuasan $100 \%$. Artinya pemberian hibah peta desa tersebut sudah sesuai dengan target yang telah di tentukan oleh pihak mitra serta sesuai dengan kebutuhan mitra. Indikator ke tiga "Pelaksanaan program berjalan lancar" memperoleh tingkat kepuasan dengan skor $86 \%$ dan sukup puas $14 \%$. Hal tersebut dikarena adanya sedikit kendala teknis di lapangan pada saat akan di lakukannya proses penyerahan peta desa. Namun hal tersebut tidak mengurangi antusiasme dari mahasiswa tim pengabdian serta pihak mitra serta tidak mengurangi esensi dan makna dari acara kegiatan penyerahan peta. Indikator ke empat "Perlunya keberlanjutan program evaluasi dan monitoring" memperoleh tingkat kepuasan dengan skor kepuasan sebanyak $100 \%$.

Keberlanjutan dari kegiatan ini yaitu berupa monitoring dan evaluasi dari kegiatan dalam memanfaatkan peta yang telah dibuat serta dapat bermanfaat bagi perangkat desa setempat dan masyakat Kelurahan Jebres kedepannya. Untuk meningkatkan pengetahuan dan pemahaman masyarakat Kelurahan Jebres agar dapat memahami wilayahnya sendiri melalui peta yang telah di buat maka kegiatan yang serupa harus dilaksanakan secara kontinyu. Hal itu merupakan rekomendasi yang diajukan berdasarkan evaluasi dan monitoring yang telah dilaksanakan. Kegiatan dapat berupa penyuluhan secara berkelanjutan kepada seluruh masyarakat Kelurahan Jebres maupun sekitarnya. Kemudian yang kedua yaitu dapat diadakan kerjasama dengan instansi yang memiliki atau berhubungan dengan unsur geografis untuk meningkatkan pemahaman berkaitan dengan info geografis yang ada di Kelurahan Jebres Kota Surakarta itu sendiri. Selain itu juga peta ini harapannya dapat menjadi acuan untuk pembangunan berkelanjutan di Kelurahan Jebres Kota Surakarta. Sehingga dapat meningkatkan potensi yang ada di Kelurahan Jebres Kota Surakarta. Banyak potensi yang ada di Kelurahan Jebres di antaranya yaitu adanya usaha kecil mandiri (UKM) berupa sanggar wayang dan seni lukis. Melalui pembuatan peta citra Kelurahan Jebres ini diharapkan selain dapat meningkatkan pemerataan pembangunan juga dapat memetakan potensi serta terus mengembangkan potensi yang ada di Kelurahan Jebres Kota Surakarta tersebut.

\section{Simpulan}

Peta desa menampilkan informasi geospasial yang dapat dimanfaatkan sebagai bahan analysis pemerintah dalam membuat suatu kebijakan. Peta Citra Kelurahan Jebres memberikan informasi tekait kenampakan permukaan bumi yang ada wilayah tersebut, seperti tutupan lahan 
permukiman, ruang terbuka hijau, lahan kosong, dan fasilitas - fasilitas umum. Informasi tersebut dapat digunakan untuk bahan perencanaan pembangunan di Kelurahan Jebres, Kecamatan Jebres, Kota Surakarta. Dari kegiatan pengabdian ini diharapkan tidak berhenti sampai disini saja artinya ada Keberlanjutan dari kegiatan ini yaitu berupa monitoring dan evaluasi dari kegiatan dalam memanfaatkan peta yang telah dibuat serta dapat bermanfaat bagi perangkat desa setempat dan masyakat Kelurahan Jebres kedepannya. Kemudian yang kedua yaitu dapat diadakan kerjasama dengan instansi yang memiliki atau berhubungan dengan unsur geografis untuk meningkatkan pemahaman berkaitan dengan info geografis yang ada di Kelurahan Jebres Kota Surakarta.

\section{Persantunan}

Terima kasih kepada seluruh pihak yang telah menjadikan kami mitra terkhusus Fakultas Geografi Universitas Muhammadiyah Surakarta yang telah mendukung kami, sehingga penulisan papper ini dapat terselesaikan hingga waktu yang telah ditentukan. Kami juga mohon maaf apabila terdapat kekurangan dalam penulisan papper ini. Kami juga berterima kasih kepada Bapak Agus Anggoro Sigit, S.Si, M.Sc selaku pencetus program 1000 Peta Desa yang lahir dari mata kuliah Manajemen Produksi Peta sehingga kami terinspirasi untuk melakukan kegiatan pengabdian masyarakat ini.

\section{Referensi}

Badan Pusat Statistik. (2021). Kecamatan Jebres Dalam Angka 2020. BPS Kota Surakarta: Surakarta.

Setyawan, D., Laila, N., \& Sudarsono, B. (2018). Analisis Potensi Desa Berbasis Sistem Informasi Geografis (Studi Kasus: Kelurahan Sumurboto, Kecamatan Banyumanik, Kabupaten Semarang). Jurnal Geodesi Undip, 7(4), 247-254.

Sukwika, T. (2018). Peran Pembangunan Infrastruktur terhadap Ketimpangan Ekonomi Antar Wilayah di Indonesia. Jurnal Wilayah dan Lingkungan, 2(1), 115-130.

Bakosurtanal. (1999). Peta RBI Digital 1:25.000 Lembar 1408-214 Jebres, Badan Koordinasi Survei dan Pemetaan Nasional, Cibinong, Bogor

Sutanto. (1986). Penginderaan Jauh Jilid I. Yogyakarta: Gadjah Mada University Press.

Bafdal, N., Amaru, K. \& Pareira, B.M.P. 2012. Bahan Ajar-Sistem Informasi Geografis. UNPAD Press: Universitas Padjadjaran.

Bafdal, N., Balis, R, L., Dwiratna, S., \& Amaru, K. (2014). Penyusunan PetaPotensi Desa Agrowisata Berbasis Masyarakat di Desa Cibuntu Kecamatan Pasawahan Kabupaten Kuningan. Jurnal Aplikasi Ipteks untuk Masyarakat, 3(2), 81-87. doi:10.24198/v3i2.8353

Waljiyanto, Rochmad, M., Iqbal, M, T., Ruli, A., Untung, R., Gondang, R., . . . Ni Putu Praja, C. (2019). Pembuatan Peta Foto Udara Kelurahan Wates. Jurnal Pengabdian dan Pengembangan Masyarakat, 2(2), 8-12. doi:10.22146/jp2m.42294 